\title{
Expression pattern and methylation of estrogen receptor $\alpha$ in breast intraductal proliferative lesions
}

\author{
XIAOYUN MAO ${ }^{1}$, ZHEN QIAO $^{1}$, CHUIFENG FAN $^{2}$, AYAO GUO $^{1}$, XINMIAO YU $^{1}$ and FENG JIN ${ }^{1}$ \\ ${ }^{1}$ Department of Breast Surgery, Department of Surgical Oncology, Research Unit of General Surgery, \\ The First Affiliated Hospital of China Medical University; ${ }^{2}$ Department of Pathology, The First Affiliated Hospital \\ and College of Basic Medical Sciences of China Medical University, Shenyang, Liaoning 110001, P.R. China
}

Received March 5, 2016; Accepted July 13, 2016

DOI: $10.3892 /$ or.2016.4988

\begin{abstract}
Intraductal proliferative lesions of the breast including usual ductal hyperplasia (UDH), atypical ductal hyperplasia (ADH) and ductal carcinoma in situ (DCIS) are associated with increased risk, albeit of greatly different magnitudes, for the subsequent development of invasive carcinoma. Estrogen receptor $\alpha(\mathrm{ER} \alpha)$ has been widely accepted as a prognostic marker and a predictor for endocrine therapy response of breast cancer. To investigate the ER $\alpha$ expression and methylation in breast intraductal proliferative lesions, we analyzed ER $\alpha$ expression in breast intraductal proliferative lesions including pure UDH $(\mathrm{N}=98)$, ADH without DCIS ( $\mathrm{N}=160)$, DCIS without invasive breast cancer $(\mathrm{N}=149)$ by immunohistochemistry. Furthermore, the methylation status of ER $\alpha$ by methylation-specific PCR (MSP) was defined in 217 cases of breast intraductal proliferative lesions. Immunohistochemistry showed that 98/98 (100\%) of the UDH cases were positive for ER $\alpha$ expression. ER $\alpha$ protein expression in ADH (132/160) $(92.5 \%)$ was higher than in DCIS (101/149) $(67.8 \%)$. But the ER $\alpha$ expression pattern was different with histological diversity of breast intraductal proliferative lesions. The average percent cells staining positive for ER $\alpha$ was $35.33 \%$ in UDH, 87.75\% in ADH and $71.45 \%$ in DCIS. ER $\alpha$ methylation in 32/60 (53.3\%) UDH, 11/77 (10.2\%) ADH and 32/80 (40.0\%) DCIS. Our results demonstrated a strong negative correlation between the percent of cells staining positive for ER $\alpha$ and $\mathrm{ER} \alpha$ methylation $(\mathrm{r}=-0.831, \mathrm{p}<0.001)$. Taken together, our results underlined that ER $\alpha$ expression or methylation may be involved in the breast carcinogenesis and advancement,
\end{abstract}

Correspondence to: Professor Feng Jin, Department of Breast Surgery, Department of Surgical Oncology, Research Unit of General Surgery, The First Affiliated Hospital of China Medical University, 155 Nanjing North Street, Heping, Shenyang, Liaoning 110001, P.R. China

E-mail: jinfeng66cn@hotmail.com

Key words: estrogen receptor $\alpha$, methylation, usual ductal hyperplasia, atypical ductal hyperplasia, ductal carcinoma in situ thus it is not parallel to breast cancer risk in breast intraductal proliferative lesions. No obvious watershed between ER $\alpha$-positive and -negative breast carcinogenesis was established. Estrogen receptor (ER) methylation or expression is a reversible signal in breast carcinogenesis which affected biological behavior of cells.

\section{Introduction}

Breast cancer subtypes have been identified based on the expression of estrogen receptor (ER), progesterone receptor (PR) and human epidermal growth factor receptor 2 (HER2). Different subgroups presented with distinct molecular backgrounds and exhibited diverse clinical behavior and different treatment response (1). Estrogen receptor $\alpha$ (ER $\alpha)$ activation by estrogenic hormones induced breast cancer cell proliferation of luminal molecular subtype (2). ER $\alpha$ has been widely accepted as a prognostic marker and a predictor for endocrine therapy response of breast cancer $(3,4)$. In general, ER $\alpha$-negative breast cancers were more aggressive and unresponsive to antiestrogens (5-7). Our previous studies demonstrated that the absence of ER $\alpha$ expression associated with aberrant methylation of its $\mathrm{CpG}$ island in a significant fraction of breast cancers (8-10).

Intraductal proliferative lesions of the breast have traditionally been divided into three categories: usual ductal hyperplasia (UDH), atypical ductal hyperplasia (ADH) and ductal carcinoma in situ (DCIS) (11). They were associated with an increased risk, albeit of greatly different magnitudes, for the subsequent development of invasive carcinoma $(12,13)$. The relative risk of subsequent invasive ductal carcinoma of breast was 1.5-2.0 times for UDH, 4-5 times for ADH (range, 2.4-13) and 8-10 times for DCIS (range, 2.4-13) (11,14-16). It was suggested that the breast intraductal proliferative lesions may be direct precursors of invasive ductal carcinoma. Many questions remain as to the role ER $\alpha$ in breast intraductal proliferative lesions. Which stage is the watershed between ER $\alpha$-positive and -negative breast carcinogenesis needs to be established. The aim of the present study was to determine the expression of ER $\alpha$ and to define the ER $\alpha$ methylation in breast intraductal proliferative lesions. 


\section{Materials and methods}

Patients and tissue samples. Fresh breast tissue samples were collected from surgical resection in the Department of Breast Surgery, the First Affiliated Hospital of China Medical University between June 2007 and December 2014, including pure UDH ( $\mathrm{N}=98)$, ADH without DCIS $(\mathrm{N}=160)$, DCIS without invasive breast cancer $(\mathrm{N}=149)$. None of patients underwent chemotherapy, radiotherapy or adjuvant treatment before operation. Patient ages ranged from 21 to 82 , with an average age of 34.5 years. Each case was reviewed independently by two pathologists with a subspecialty focus in breast pathology, and only those cases that both pathologists finally reached unanimous diagnosis were used. In case of insufficient or unattainable material, original tissue blocks were reprocessed and new slides were created. All sections were reviewed for a comprehensive list of pathologic features, including margins (close margins were defined as tissue-free margins $<1 \mathrm{~mm}$ ), the presence of concomitant $\mathrm{UDH}, \mathrm{ADH}$, DCIS and IDC. Pathology classification was according to the WHO criteria published by Tavassoli (17-19). The study was approved by the regional Ethics Committee of China Medical University.

Immunohistochemical staining. Formalin-fixed, paraffinembedded specimens were cut into $4 \mu \mathrm{m}$-thick sequential sections. The sections were dewaxed in xylene and rehydrated stepwise in ethanol. Then the sections were boiled in citrate buffer (pH 6.0) for $90 \mathrm{sec}$ in an autoclave. Endogenous peroxidase activity and non-specific binding were blocked with $3 \% \mathrm{H}_{2} \mathrm{O}_{2}$ and non-immune sera, respectively. The sections were then incubated with primary rabbit anti-human ER $\alpha$ polyclonal antibody F-10 (sc-8002, dilution 1:400; Santa Cruz Biotechnology, Inc.) overnight at $4^{\circ} \mathrm{C}$. Thereafter, the Catalyzed Signal Amplification System (Maixin Biotechnology, Fuzhou, China) was used for ER $\alpha$ staining according to the manufacturer's instructions. For the negative control, phosphate-buffered saline (PBS) was used instead of primary antibodies. We also adopted the German semi-quantitative scoring system in combination of the staining intensity and area extent, which has been widely accepted and used in previous studies (20-22). Every lesion was given a score according to the intensity of the nucleic staining (no staining, 0 ; weak staining, 1; moderate staining, 2; strong staining, 3) and the extent of stained cells $(0 \%, 0 ; 1-10 \%, 1 ; 11-50 \%, 2$; $51-80 \%, 3 ; 81-100 \%, 4$; negative, $0 \%$ area staining; focally positive, $1-80 \%$ area staining; diffusely positive, $81-100 \%$ area staining). The final immunoreactive score was determined by multiplying the intensity scores with the extent of positivity scores of stained cells, with the minimum score of 0 and a maximum score of $12(20,21)$. Slides were independently examined by two pathologists as previously mentioned. If there was a discrepancy in individual scores, both pathologists re-evaluated them together until a consensus agreement was reached before combining the individual scores. To obtained statistical results, a final score $\leq 1$ was considered as negative, while scores $\geq 2$ were considered as positive.

DNA extraction and bisulphate modification. Genomic DNA was extracted by solubilization in an SDS/proteinase K solu- tion, followed by phenol/chloroform extraction and ethanol precipitation. Sodium bisulphate conversion was done on $2 \mu \mathrm{g}$ of sample DNA per sample using previously described methods to convert all unmethylated cytosines to uracils, while leaving methylcytosines unaltered. Alkali-denatured DNA was incubated in $3 \mathrm{~mol} / 1 \mathrm{NaHSO}_{3}$ and $0.5 \mathrm{mmol} /$ hydroquinone for $16 \mathrm{~h}$ at $54^{\circ} \mathrm{C}$. Modified DNA was purified using the Wizard DNA Clean-Up System (Promega, Madison, WI, USA) and eluted into $50 \mu \mathrm{l}$ of sterile water. DNA was precipitated with $0.5 \mathrm{~mol} / \mathrm{l}$ ammonium acetate ( $\mathrm{pH} 4.6), 1.5 \mu \mathrm{l}$ of $20 \mathrm{mg} / \mathrm{ml}$ glycogen, and ethanol and then resuspend in Tris-EDTA.

Methylation-specific PCR (MSP) of ER $\alpha$. We selected ER1, ER3, ER4 and ER5 for MSP from the six primer pairs previously described $(8,9)$ because these covered the most significant methylated loci. The oligonucleotides of primers were synthesized by Sangon Biotech Co., Ltd. (Shanghai, China). PCR was carried out initial denaturation at $95^{\circ} \mathrm{C}$ for $10 \mathrm{~min}$, followed by 14 cycles of $94^{\circ} \mathrm{C}$ for $30 \mathrm{sec}, 62^{\circ} \mathrm{C}$ (ER1) or $59^{\circ} \mathrm{C}(\mathrm{ER} 3$, ER4 and ER5) for $45 \mathrm{sec}\left(-0.5^{\circ} \mathrm{C}\right.$ decreased/each cycle $), 72^{\circ} \mathrm{C}$ for $1 \mathrm{~min}$, then followed by 30 cycles of $94^{\circ} \mathrm{C}$ for $30 \mathrm{sec}, 55^{\circ} \mathrm{C}$ (ER1) or $52^{\circ} \mathrm{C}$ (ER, ER4 and ER5) for $45 \mathrm{sec}, 72^{\circ} \mathrm{C}$ for $45 \mathrm{sec}$, ending with a final extension of $72{ }^{\circ} \mathrm{C}$ for $10 \mathrm{~min}$ and a quick chill to $4^{\circ} \mathrm{C}$. The products were subjected to $3 \%$ agarose gel electrophoresis at $100 \mathrm{~V}$ for $60 \mathrm{~min}$ and visualized by UV light. DNA from lymphocytes of healthy volunteers treated with SssI methyltransferase (New England Biolabs, Beverly, MA, USA) and then subjected to bisulfite modification was used as positive control for methylated alleles and water was used as negative controls.

Statistical analysis. Statistical analysis was carried out using SPSS version 13.0 (SPSS, Inc., Chicago, IL, USA). We compared ER $\alpha$ expression or methylation in breast intraductal proliferative lesions including UDH, ADH and DCIS using Chi-square tests of significance. Separate analyses were carried out for percent staining and the percent-by-intensity product term, using both the weighted averages as well as maximal values for percent staining. Differences were considered statistically significant at $p<0.05$. The non-parametric correlations of ER $\alpha$ expression with methylation were analyzed with Spearman's test.

Ethics statement. The study was approved by the regional Ethics Committee of China Medical University. Subjects were also given sufficient explanation of the study in writing, and provided with written informed consent to participate. All patients providing tissues of intraductal proliferative lesions signed a consent form prior to breast surgery to allow for this research to be undertaken.

\section{Results}

ER $\alpha$ protein expression in breast intraductal proliferative lesions including $U D H, A D H$ and DCIS. ER $\alpha$ has nuclear staining. UDH were positive for $\mathrm{ER} \alpha$ expression in 98/98 $(100 \%)$ cases. ER $\alpha$ protein expression in ADH $(132 / 160)$ $(92.5 \%)$ was higher than in DCIS (101/149) $(67.8 \%)(\mathrm{p}<0.05$, Fig. 1). Although the positive rate of ER $\alpha$ expression in UDH was higher than in ADH. The expression pattern of ER $\alpha$ 


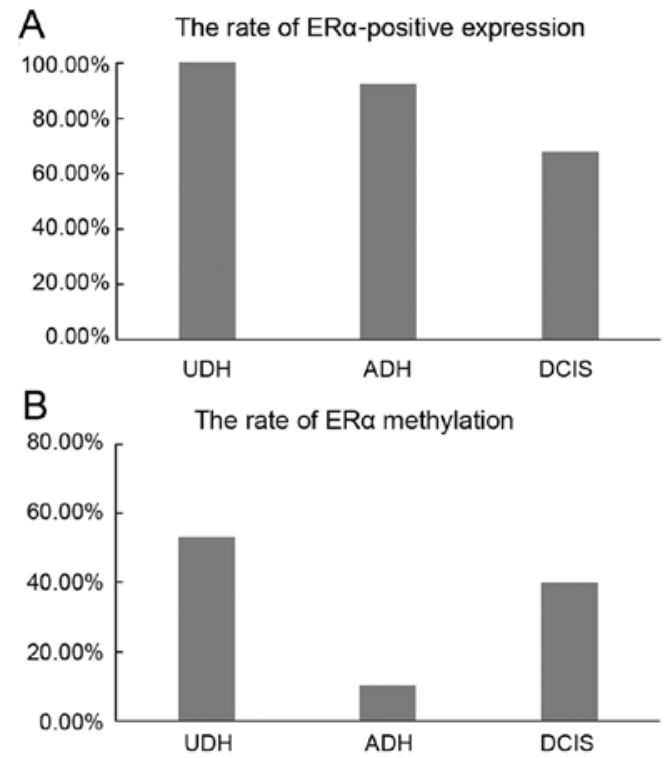

Figure 1. The rate of ER $\alpha$ expression and methylation in breast intraductal hyperplasia including UDH, ADH and DCIS. The rate of ER $\alpha$ (A) expression and (B) methylation in UDH, ADH and DCIS. ER $\alpha$, estrogen receptor $\alpha$; UDH, usual ductal hyperplasia; ADH, atypical ductal hyperplasia; DCIS, ductal carcinoma in situ.

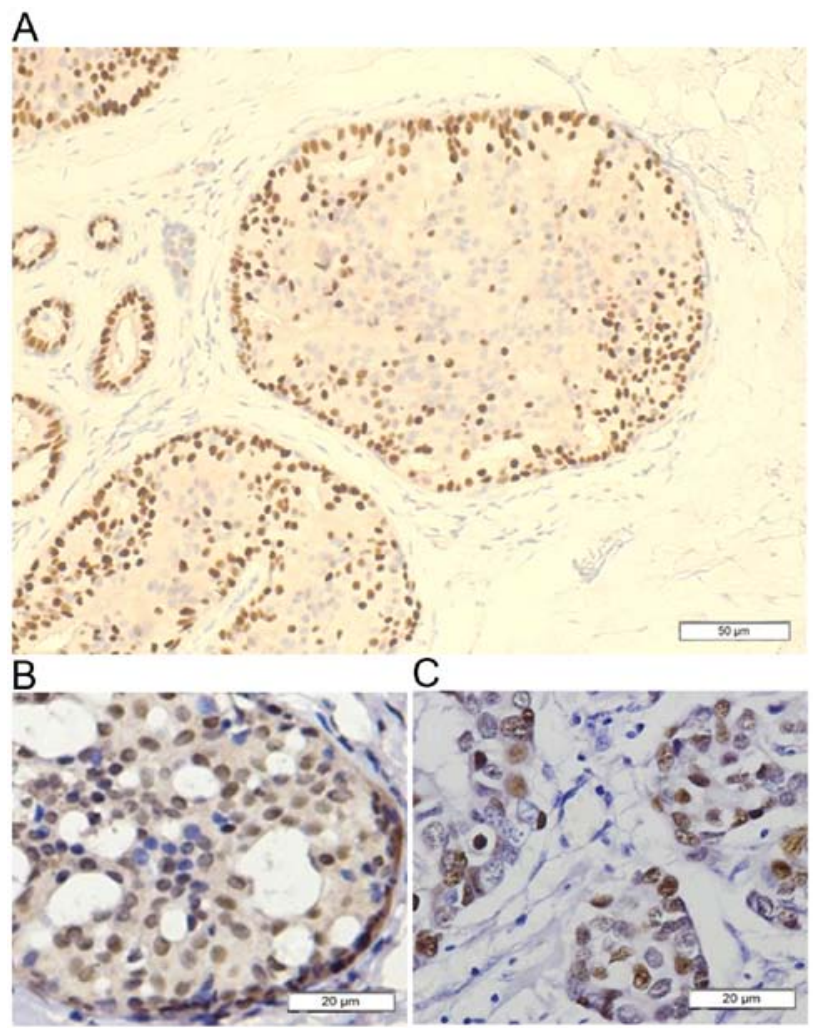

Figure 2. The immunohistochemical staining of ER $\alpha$ in UDH. (A) ER $\alpha$-positive staining located mainly in the hyperplasia nucleus of UDH (x200). (B and C) The ER $\alpha$-positive cells uniformly scattered in the benign proliferative ductal epithelial cells of UDH (x400). ER $\alpha$, estrogen receptor $\alpha$; UDH, usual ductal hyperplasia.

was different with histological diversity of breast intraductal proliferative lesions. Figs. 2-4 show immunohistochemical staining of $\mathrm{ER} \alpha$ in the breast intraductal proliferative lesions.
A
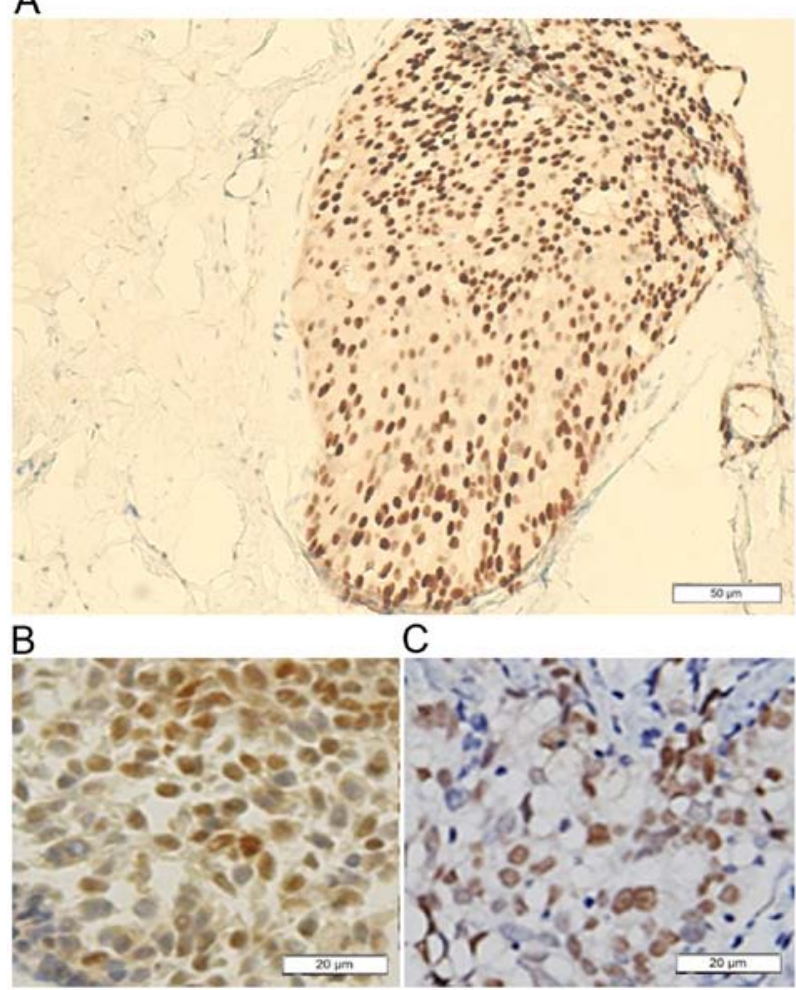

Figure 3. The immunohistochemical staining of ER $\alpha$ in ADH. (A) ER $\alpha$-positive staining located mainly in the atypical nucleus of ADH (x200). (B and C) The ER $\alpha$-positive cells clustered in ductal hyperplasia with thick cell layers which exhibited positivity of contiguous cells accounting for the majority in the lesions (x400). ER $\alpha$, estrogen receptor $\alpha$; ADH, atypical ductal hyperplasia.

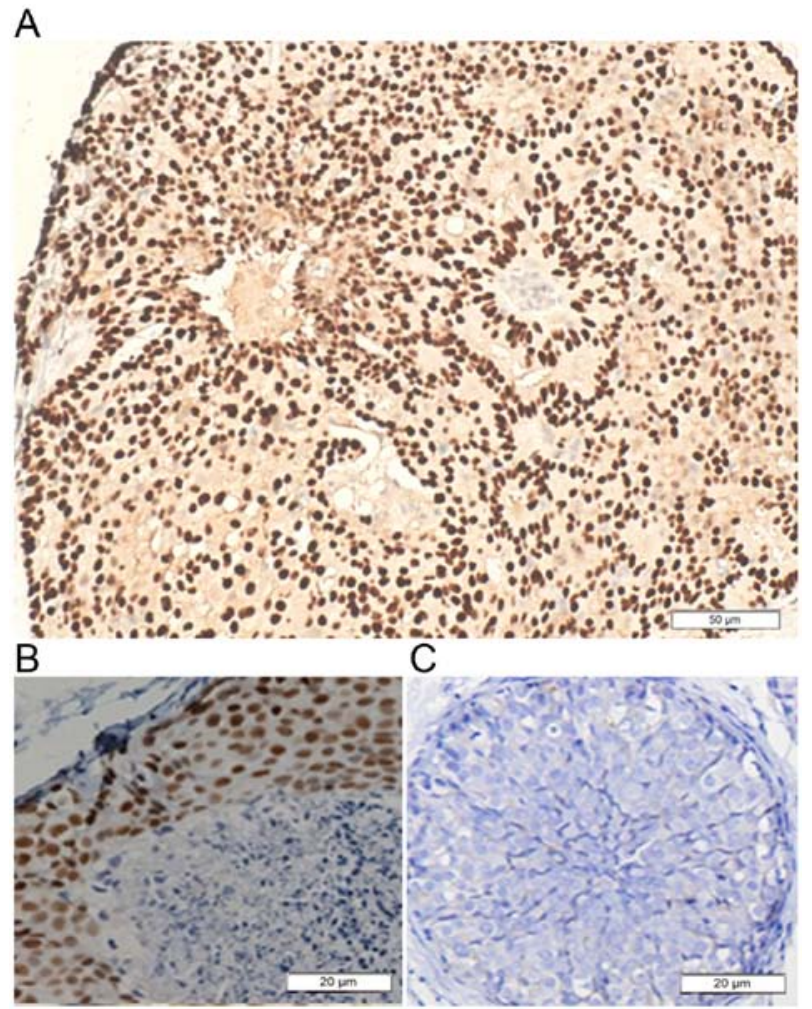

Figure 4. The immunohistochemical staining of ER $\alpha$ in DCIS. (A) All or none ER $\alpha$-positive cells constructed the morphological variants (x200). (B) ER $\alpha$-positive staining located mainly in the tumor cells of DCIS (x400). (C) None of ER $\alpha$-positive cells constructed the lesion of DCIS (x400). ER $\alpha$, estrogen receptor $\alpha$; DCIS, ductal carcinoma in situ. 


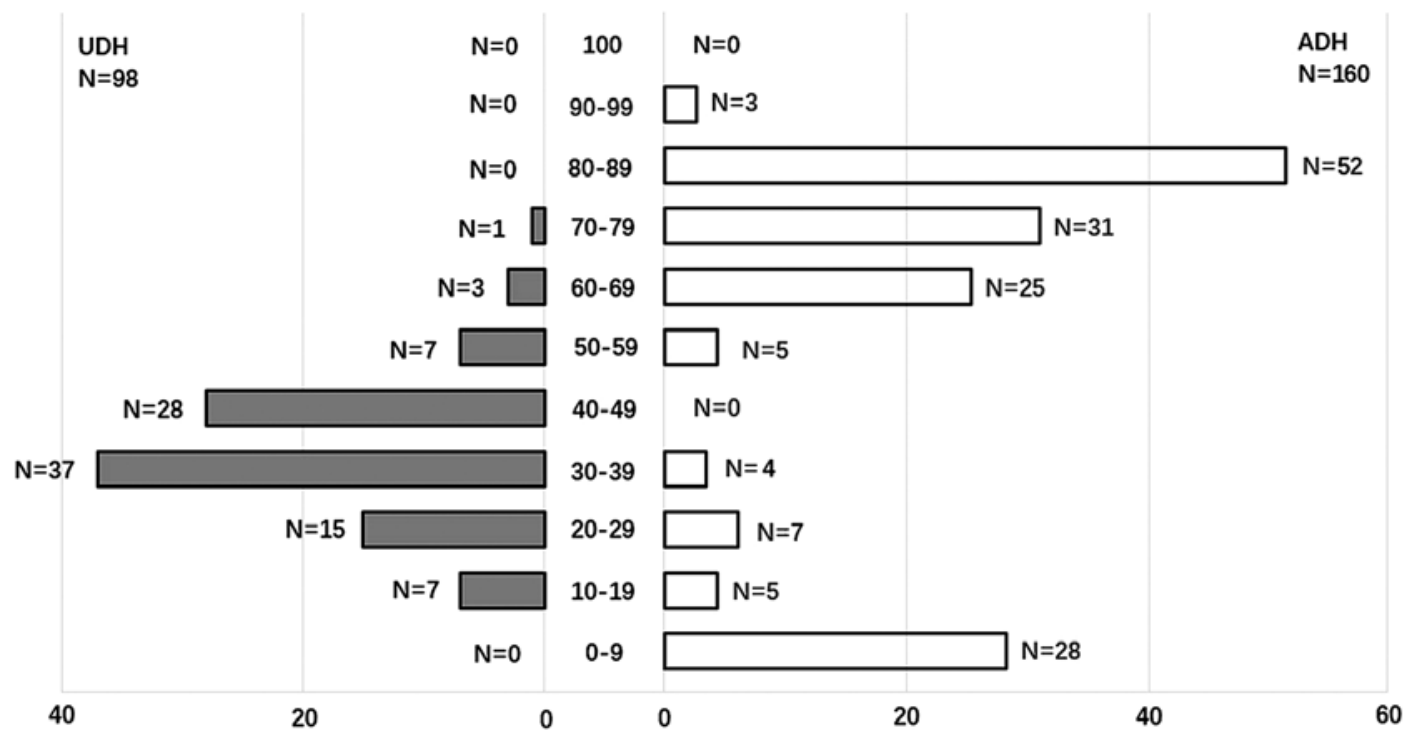

Figure 5. The percent of cells staining positive for ER $\alpha$ in UDH and ADH. ER $\alpha$, estrogen receptor $\alpha$; UDH, usual ductal hyperplasia; ADH, atypical ductal hyperplasia.

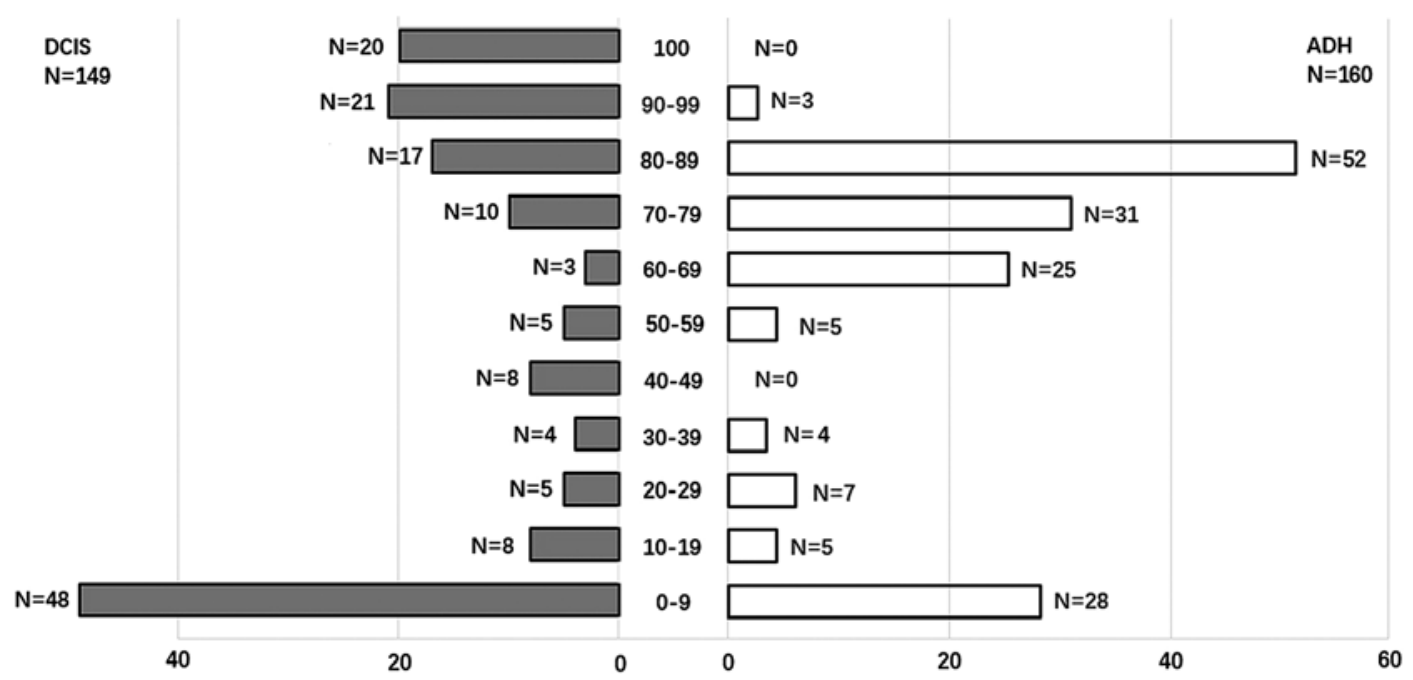

Figure 6. The percent of cells staining positive for ER $\alpha$ in DCIS and ADH. ER $\alpha$, estrogen receptor $\alpha$; DCIS, ductal carcinoma in situ; ADH, atypical ductal hyperplasia.

The average percent of cells staining positive for ER $\alpha$ was $35.33 \%$ in UDH, $87.75 \%$ in ADH and $71.45 \%$ in DCIS. ADH was more likely to show increased ER percent of cell staining, with mean percent of cells staining of $87.75 \%$. As can be seen in Figs. 5 and 6, 116/160 (72.5\%) of the ADH lesions had $\mathrm{ER} \alpha$ staining in over half of the atypical cells. Conversely, only 11/98 (11.2\%) of the UDH lesions demonstrated ER $\alpha$ expression in $>50 \%$ of the hyperplasia cells. DCIS had ER $\alpha$ staining in over half of the tumor cells (76/149) (51.0\%). In contrast, UDH showed less ER $\alpha$ staining (Fig. 5). As can be seen in Fig. 2, the ER $\alpha$-positive cells uniformly scattered in the benign proliferative ductal epithelial cells of UDH. In $\mathrm{ADH}$, the ER $\alpha$-positive cells clustered in ductal hyperplasia with thick cell layers which exhibited positivity of contiguous cells accounting for the majority in the lesions (Fig. 3). In some cases of DCIS, all or none ER $\alpha$-positive cells constructed the morphological variants (Fig. 4). On the whole, the stain pattern was variable in DCIS. It exhibits considerable tumor heterogeneity, and in a given patient can have more than a single microscopic structural, cytologic, or immunocytochemical phenotype of $\mathrm{ER} \alpha$.

Methylation status of the ER $\alpha$ promoter in breast intraductal proliferative lesions including UDH, ADH and DCIS. Adequate tissue of UDH, ADH and DCIS for DNA extraction was available for 248/407 cases. Samples were classified as methylated if one or more regions were positive for MSP. Bisulphite-treated DNA was amplified with primers for ER1, ER3, ER4 and ER5 as shown in Fig. 7. We detected ER $\alpha$ methylation in 32/60 (53.3\%) UDH, 11/77 (10.2\%) ADH and 32/80 (40.0\%) DCIS (Table I and Fig. 1). There was significant difference between the methylation in ADH and in DCIS, in $\mathrm{UDH}$ and in ADH. There was no significant difference between the methylation in UDH and in DCIS, $\mathrm{p}>0.05$. There 
Table I. The methylation and expression of ER $\alpha$ in UDH, ADH and DCIS.

\begin{tabular}{lrrrrr}
\hline & \multicolumn{2}{c}{ ER $\alpha$ methylation } & & \multicolumn{2}{c}{ ER $\alpha$ expression } \\
\cline { 2 - 3 } \cline { 6 - 7 } Groups & Tn & N (\%) & & Tn & N (\%) \\
\hline UDH & 60 & $32(53.3)$ & & 98 & $98(100.0)$ \\
ADH & 108 & $11(10.2)^{\mathrm{a}}$ & & 160 & $132(92.5)^{\mathrm{a}}$ \\
DCIS & 80 & $32(40.0)^{\mathrm{b}}$ & & 149 & $101(67.8)^{\mathrm{a}, \mathrm{b}}$
\end{tabular}

${ }^{\mathrm{a}} \mathrm{P}<0.05$, compared with UDH. ${ }^{\mathrm{b}} \mathrm{P}<0.05$, compared with $\mathrm{ADH}$. ER $\alpha$, estrogen receptor $\alpha$; UDH, usual ductal hyperplasia; $\mathrm{ADH}$, atypical ductal hyperplasia; DCIS, ductal carcinoma in situ; Tn, total number.

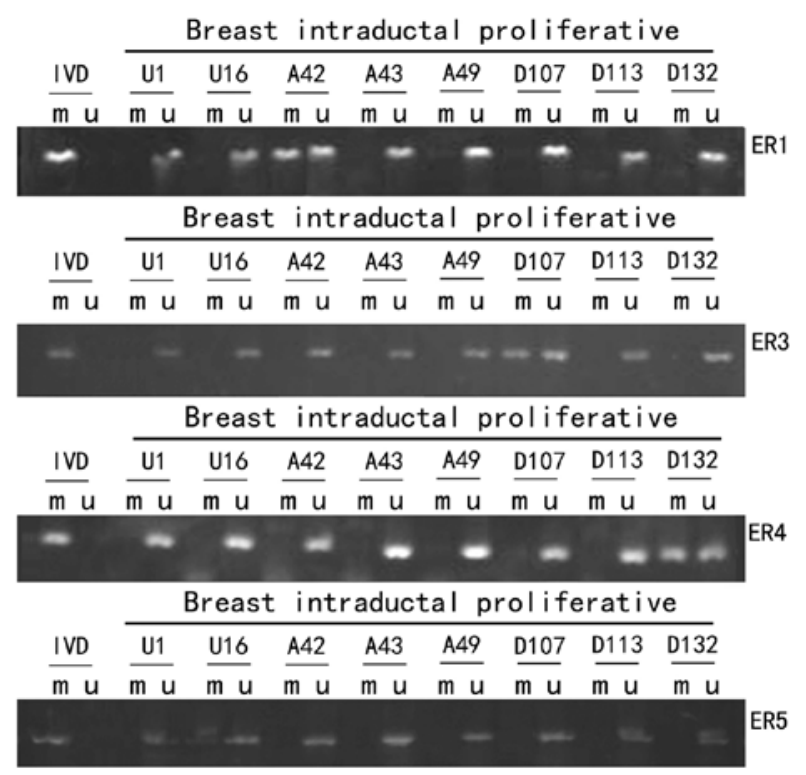

Figure 7. ER $\alpha$ methylation analysis of breast intraductal hyperplasia including UDH, ADH and DCIS. MSP was performed on bisulphate-treated DNA from intraductal proliferative lesions of breast. DNA bands in lanes labeled with $U$ indicate PCR products amplified with primers recognizing the unmethylated promoter sequence. DNA bands in lanes labeled with M represent amplified products with methylation-specific primers. IVD serves as positive control for the $\mathrm{U}$ and $\mathrm{M}$ reaction, respectively. ER $\alpha$, estrogen receptor $\alpha$; UDH, usual ductal hyperplasia; ADH, atypical ductal hyperplasia; DCIS, ductal carcinoma in situ; MSP, methylation-specific PCR; IVD, in vitro methylated DNA.

was no significant difference in the overall average percent methylation between the four primers in the non-invasive lesions.

Correlation analysis of ER $\alpha$ methylation and expression. In Spearman's correlation test, ER $\alpha$ methylation and expression had inverse patterns of alterations in breast intraductal proliferative lesions including UDH, ADH and DCIS. As shown in Table II, there is a strong negative correlation $(r=-0.831$, $\mathrm{p}<0.001$ ) between the percent cells staining positive for ER $\alpha$ expression and ER $\alpha$ methylation, and a weaker but statistically significant negative correlation between ER $\alpha$ methylation and expression $(r=-0.401, \mathrm{p}<0.001)$.
Table II. Correlation of ER $\alpha$ expression with ER $\alpha$ methylation in breast intraductal proliferative lesions.

\begin{tabular}{lccc}
\hline & \multicolumn{2}{c}{ ER $\alpha$ methylation } & \\
\cline { 2 - 3 } & Methylation & Unmethylation & $\begin{array}{c}\text { Statistical } \\
\text { values }\end{array}$ \\
\hline $\begin{array}{l}\text { ER } \alpha \text { expression } \\
\text { positive }\end{array}$ & 42 & 157 & $\mathrm{r}=-0.401$ \\
$\begin{array}{l}\text { ER } \alpha \text { expression } \\
\text { negative }\end{array}$ & 33 & 16 & $\mathrm{p}<0.001$ \\
\hline
\end{tabular}

$\mathrm{ER} \alpha$, estrogen receptor $\alpha$.

\section{Discussion}

A history of proliferative breast disease is a significant risk factor for development of invasive breast cancer. UDH is considered to represent a benign proliferation of ductal epithelial cells, and patients with UDH carried only a small increased risk of developing subsequent breast cancer compared with patients without proliferative breast disease (23). ADH indicates that there are more cells lining the duct than would normally be there, and some of these cells are not typical - they are irregular in shape and size. Usually, a milk duct is lined with one even layer of uniformly shaped cells, but in ductal hyperplasia there may be many layers of cells (24). Patients diagnosed with ADH, have a risk of developing breast cancer 4-5 times the average lifetime risk. DCIS is a proliferation of malignant epithelial cells confined to the ductolobular system of the breast. It is considered a precursor lesion for invasive breast cancer. Estrogen plays a major role in promoting normal growth of breast epithelium and is thought to be important in the pathogenesis of breast cancer via the uptake into the cell through the mechanism of the ER (25). The role of ER $\alpha$ in breast intraductal proliferative lesions is a major dilemma. Which stage is the watershed between ER $\alpha$-positive and -negative breast carcinogenesis needs to be established.

In this study we confirmed that $98 / 98(100 \%)$ of the UDH cases were positive for ER $\alpha$ expression. ER $\alpha$ protein expression in ADH (132/160) $(92.5 \%)$ was higher than in DCIS (101/149)(67.8\%). But the ER $\alpha$ expression pattern was different with histological diversity of breast intraductal proliferative lesions. The average percent of cells staining positive for ER $\alpha$ was $35.33 \%$ in UDH, $87.75 \%$ in ADH and $71.45 \%$ in DCIS. ER $\alpha$ methylation in 32/60 (53.3\%) UDH, 11/77 (10.2\%) ADH and $32 / 80(40.0 \%)$ DCIS. Our results demonstrated a strong negative correlation between the percent of cells staining positive for $\mathrm{ER} \alpha$ and $\mathrm{ER} \alpha$ methylation $(\mathrm{r}=-0.831, \mathrm{p}<0.001)$; and weak to moderate negative correlations between ER $\alpha$ expression and methylation $(\mathrm{r}=-0.401, \mathrm{p}<0.001)$. Could that mean that methylation alone is not enough to result in negative $\mathrm{ER} \alpha$ expression and that in $\mathrm{ER} \alpha$-negative cases there are additional genetic or epigenetic events that result in loss of staining? The ER $\alpha$ expression detected by immumohistochemistry is to understand the distribution and localization of ER $\alpha$ within the tissue examined. The MSP requires only 
small quantities of DNA, in analysis of ER $\alpha$ methylation patterns in $\mathrm{CpG}$ islands in a small fraction of cells. So we found strong negative correlation between the percent of cells staining positive for $\operatorname{ER} \alpha$ and $\operatorname{ER} \alpha$ methylation. The downregulation of $\mathrm{ER} \alpha$ through promoter methylation was highly prevalent in breast intraductal proliferative lesions, which is consistent with previously published reports (8-10). Our data revealed that the levels of ER $\alpha$ protein expression diminished with the methylation of ER $\alpha$. It is possible that the percent of cells staining positive for ER $\alpha$ can reflect the status of ER $\alpha$ more accurately.

A few recent studies have examined ER $\alpha$ expression in ductal neoplasia. In our cohort, the ER $\alpha$-positive cells uniformly scattered in the terminal duct lobular units which contains benign proliferative ductal epithelial cells of UDH. ADH may represent the first clonal neoplastic expansion of these cells (24). Immunohistochemical study showed that ER $\alpha$-positive cells clustered in ductal hyperplasia with thick cell layers which exhibited positivity of contiguous cells accounting for the majority in the lesions. It has been reported that $\mathrm{ER} \alpha$ is the primary ER for mammary epithelial cell proliferation and differentiation (26). Mammary glands of adult female ER $\alpha$ knock-out mice fail to respond to ovarian hormones resulting at rudimentary duct stage without further development (27). In this study we found the average percent of cells staining positive for $\operatorname{ER} \alpha$ was higher in $\mathrm{ADH}$ than in UDH. The upregulation of ER $\alpha$ expression involved in the conversion of UDH to atypia hyperplasia. DCIS represented a heterogeneous group of lesions with diverse malignant potential (28). The majority of available evidence suggests that ER expression range from very high to very low levels characteristic $(29,30)$. The staining pattern was erratic in DCIS in our results which was consistent with previous published research (31). We thought that the DCIS is a heterogeneous group of lesions with diverse pattern of ER $\alpha$ expression resulted from the chaos methylation of ER $\alpha$. The breast cancer risk is not consistent with the ER $\alpha$ expression or methylation. Possibly the ER $\alpha$ expression or methylation were not the initial factors in breast carcinogenesis. The ER $\alpha$ methylation is a common epigenetic signaling tool that is used to control ER expression. One of the most provocative recent observations in human solid tumors is the discovery of large hypomethylated blocks in cancer epigenetics (32). DNA methylation is a reversible signal, similar to other physiological biochemical modifications $(33,34)$. The altered DNA methylation in $\mathrm{CpG}$ islands in solid tumors associated with loss of both epigenetic and gene expression regulation, resulting in hyper-variability of gene expression $(35,36)$. These changes could even have interaction with the change of biological behavior of cells which resulted from the loss of structural integrity of heterochromatin.

DNA methylation is a reversible biological signal $(34,37)$. Our new working hypothesis is that the methylation and expression of ER $\alpha$ shows dynamic variation in breast carcinogenesis. Our previous study indicated that breast cancer can convert into other molecular subtypes with the treatment of neoadjuvant chemotherapy (38). ER $\alpha$ expression or methylation may be involved in the breast carcinogenesis and advancement, thus it is not parallel to breast cancer risk in breast intraductal proliferative lesions. No obvious watershed exists between
ER $\alpha$-positive and -negative breast carcinogenesis. ER methylation or expression is a reversible signal in breast carcinogenesis affecting biological behavior of cells.

\section{Acknowledgements}

This study was supported by the Project of Scientific Technology and Social Development, Liaoning (no. 2009225008-3) and the National Natural Science Foundation of China (nos. 81201886 and 81341063). The funders had no role in study design, data collection and analysis, decision to publish, or preparation of the manuscript.

\section{References}

1. Liu CY, Hung MH, Wang DS, Chu PY, Su JC, Teng TH, Huang CT, Chao TT, Wang CY, Shiau CW, et al: Tamoxifen induces apoptosis through cancerous inhibitor of protein phosphatase $2 \mathrm{~A}$-dependent phospho-Akt inactivation in estrogen receptor-negative human breast cancer cells. Breast Cancer Res 16: 431, 2014.

2. Miano V, Ferrero G, Reineri S, Caizzi L, Annaratone L, Ricci L, Cutrupi S, Castellano I, Cordero F and De Bortoli M: Luminal long non-coding RNAs regulated by estrogen receptor alpha in a ligand-independent manner show functional roles in breast cancer. Oncotarget, 7: 3201-3216, 2016.

3. Goldhirsch A, Gelber RD and Coates AS: What are the long-term effects of chemotherapy and hormonal therapy for early breast cancer? Nat Clin Pract Oncol 2: 440-441, 2005.

4. Chen JQ and Russo J: ERalpha-negative and triple negative breast cancer: Molecular features and potential therapeutic approaches. Biochim Biophys Acta 1796: 162-175, 2009.

5. Kennecke H, Yerushalmi R, Woods R, Cheang MC, Voduc D, Speers CH, Nielsen TO and Gelmon K: Metastatic behavior of breast cancer subtypes. J Clin Oncol 28: 3271-3277, 2010.

6. Giacinti L, Claudio PP, Lopez M and Giordano A: Epigenetic information and estrogen receptor alpha expression in breast cancer. Oncologist 11: 1-8, 2006.

7. Ottaviano YL, Issa JP, Parl FF, Smith HS, Baylin SB and Davidson NE: Methylation of the estrogen receptor gene $\mathrm{CpG}$ island marks loss of estrogen receptor expression in human breast cancer cells. Cancer Res 54: 2552-2555, 1994.

8. Wei J, Han B, Mao XY, Wei MJ, Yao F and Jin F: Promoter methylation status and expression of estrogen receptor alpha in familial breast cancer patients. Tumour Biol 33: 413-420, 2012.

9. Jing MX, Mao XY, Li C, Wei J, Liu C and Jin F: Estrogen receptor-alpha promoter methylation in sporadic basal-like breast cancer of Chinese women. Tumour Biol 32: 713-719, 2011.

10. Zhao L, Wang L, Jin F, Ma W, Ren J, Wen X, He M, Sun M, Tang $\mathrm{H}$ and Wei M: Silencing of estrogen receptor alpha (ERalpha) gene by promoter hypermethylation is a frequent event in Chinese women with sporadic breast cancer. Breast Cancer Res Treat 117: 253-259, 2009.

11. Ellis IO: Intraductal proliferative lesions of the breast: Morphology, associated risk and molecular biology. Mod Pathol 23 (Suppl 2): S1-S7, 2010.

12. Hilton HN, Kantimm S, Graham JD and Clarke CL: Changed lineage composition is an early event in breast carcinogenesis. Histol Histopathol 28: 1197-1204, 2013.

13. Beer N, Ali AS, de Savigny D, Al-Mafazy AW, Ramsan M, Abass AK, Omari RS, Björkman A and Källander K: System effectiveness of a targeted free mass distribution of long lasting insecticidal nets in Zanzibar, Tanzania. Malar J 9: 173, 2010.

14. Bane A: Ductal carcinoma in situ: What the pathologist needs to know and why. Int J Breast Cancer 2013: 914053, 2013.

15. Goodwin A, Parker S, Ghersi D and Wilcken N: Post-operative radiotherapy for ductal carcinoma in situ of the breast. Cochrane Database Syst Rev 11: CD000563, 2013.

16. Costarelli L, Campagna D, Mauri M and Fortunato L: Intraductal proliferative lesions of the breast-terminology and biology matter: Premalignant lesions or preinvasive cancer. Int J Surg Oncol 2012: 501904, 2012.

17. Tavassoli FA: Correlation between gene expression profiling-based molecular and morphologic classification of breast cancer. Int J Surg Pathol 18 (Suppl): 167S-169S, 2010. 
18. Tavassoli FA: Lobular and ductal intraepithelial neoplasia. Pathologe 29 (Suppl 2): 107-111, 2008.

19. Tavassoli FA: Breast pathology: Rationale for adopting the ductal intraepithelial neoplasia (DIN) classification. Nat Clin Pract Oncol 2: 116-117, 2005.

20. Kok LF, Lee MY, Tyan YS, Wu TS, Cheng YW, Kung MF, Wang PH and Han CP: Comparing the scoring mechanisms of p16INK4a immunohistochemistry based on independent nucleic stains and independent cytoplasmic stains in distinguishing between endocervical and endometrial adenocarcinomas in a tissue microarray study. Arch Gynecol Obstet 281: 293-300, 2010.

21. Koo CL, Kok LF, Lee MY, Wu TS, Cheng YW, Hsu JD, Ruan A, Chao KC and Han CP: Scoring mechanisms of p16INK4a immunohistochemistry based on either independent nucleic stain or mixed cytoplasmic with nucleic expression can significantly signal to distinguish between endocervical and endometrial adenocarcinomas in a tissue microarray study. J Transl Med 725 , 2009.

22. Manne U, Myers RB, Moron C, Poczatek RB, Dillard S, Weiss H, Brown D, Srivastava $S$ and Grizzle WE: Prognostic significance of Bcl-2 expression and p53 nuclear accumulation in colorectal adenocarcinoma. Int J Cancer 74: 346-358, 1997.

23. Gong G, DeVries S, Chew KL, Cha I, Ljung BM and Waldman FM: Genetic changes in paired atypical and usual ductal hyperplasia of the breast by comparative genomic hybridization. Clin Cancer Res 7: 2410-2414, 2001.

24. Di Bonito M, Cantile M, De Cecio R, Liguori G and Botti G. Prognostic value of molecular markers and cytogenetic alterations that characterize breast cancer precursor lesions (Review). Oncol Lett 6: 1181-1183, 2013.

25. Barr FE, Degnim AC, Hartmann LC, Radisky DC, Boughey JC, Anderson SS, Vierkant RA, Frost MH, Visscher DW and Reynolds C: Estrogen receptor expression in atypical hyperplasia: Lack of association with breast cancer. Cancer Prev Res (Phila) 4: 435-444, 2011.

26. Tan H, Zhong Y and Pan Z: Autocrine regulation of cell proliferation by estrogen receptor-alpha in estrogen receptoralpha-positive breast cancer cell lines. BMC Cancer 9: 31, 2009.
27. Okolowsky N, Furth PA and Hamel PA: Oestrogen receptor-alpha regulates non-canonical Hedgehog-signalling in the mammary gland. Dev Biol 391: 219-229, 2014.

28. Sprague BL, Trentham-Dietz A and Burnside ES: Socioeconomic disparities in the decline in invasive breast cancer incidence. Breast Cancer Res Treat 122: 873-878, 2010.

29. Allred DC, Wu Y, Mao S, Nagtegaal ID, Lee S, Perou CM, Mohsin SK, O'Connell P, Tsimelzon A and Medina D: Ductal carcinoma in situ and the emergence of diversity during breast cancer evolution. Clin Cancer Res 14: 370-378, 2008.

30. Leonard GD and Swain SM: Ductal carcinoma in situ, complexities and challenges. J Natl Cancer Inst 96: 906-920, 2004.

31. Allred DC, Brown P and Medina D: The origins of estrogen receptor alpha-positive and estrogen receptor alpha-negative human breast cancer. Breast Cancer Res 6: 240-245, 2004.

32. Hovestadt V, Jones DT, Picelli S, Wang W, Kool M, PA, Sultan M, Stachurski K, Ryzhova M, Warnatz HJ, et al: Decoding the regulatory landscape of medulloblastoma using DNA methylation sequencing. Nature 510: 537-541, 2014.

33. Ballestar E and Esteller M: Epigenetic gene regulation in cancer. Adv Genet 61: 247-267, 2008.

34. Ramchandani S, Bhattacharya SK, Cervoni N and Szyf M: DNA methylation is a reversible biological signal. Proc Natl Acad Sci USA 96: 6107-6112, 1999.

35. Timp W, Bravo HC, McDonald OG, Goggins M, Umbricht C, Zeiger M, Feinberg AP and Irizarry RA: Large hypomethylated blocks as a universal defining epigenetic alteration in human solid tumors. Genome Med 6: 61, 2014.

36. Hansen KD, Timp W, Bravo HC, Sabunciyan S, Langmead B McDonald OG, Wen B, Wu H, Liu Y, Diep D, et al: Increased methylation variation in epigenetic domains across cancer types. Nat Genet 43: 768-775, 2011.

37. Reik W, Dean W and Walter J: Epigenetic reprogramming in mammalian development. Science 293: 1089-1093, 2001.

38. Lv M, Li B, Li Y, Mao X, Yao F and Jin F: Predictive role of molecular subtypes in response to neoadjuvant chemotherapy in breast cancer patients in Northeast China. Asian Pac J Cancer Prev 12: 2411-2417, 2011. 